\title{
Methanol in Plant Life
}

\author{
Yuri L. Dorokhov ${ }^{1,2 *}$, Ekaterina V. Sheshukova ${ }^{1}$ and Tatiana V. Komarova ${ }^{1,2}$ \\ ${ }^{1}$ N.I. Vavilov Institute of General Genetics, Russian Academy of Sciences, Moscow, Russia, ${ }^{2}$ A. N. Belozersky Institute \\ of Physico-Chemical Biology, Lomonosov Moscow State University, Moscow, Russia
}

\section{OPEN ACCESS}

Edited by:

Jens Rohloff,

Norwegian University of Science and Technology, Norway

Reviewed by:

Vincenzo Lionetti,

Università degli Studi di Roma La

Sapienza, Italy

Nora Gigli Bisceglia,

Norwegian University of Science

and Technology, Norway

*Correspondence:

Yuri L. Dorokhov

dorokhov@belozersky.msu.ru

Specialty section:

This article was submitted to

Plant Metabolism

and Chemodiversity,

a section of the journal

Frontiers in Plant Science

Received: 17 August 2018

Accepted: 18 October 2018

Published: 09 November 2018

Citation:

Dorokhov YL, Sheshukova EV and Komarova TV (2018) Methanol in Plant Life. Front. Plant Sci. 9:1623. doi: 10.3389/fp/s.2018.01623
Until recently, plant-emitted methanol was considered a biochemical by-product, but studies in the last decade have revealed its role as a signal molecule in plantplant and plant-animal communication. Moreover, methanol participates in metabolic biochemical processes during growth and development. The purpose of this review is to determine the impact of methanol on the growth and immunity of plants. Plants generate methanol in the reaction of the demethylation of macromolecules including DNA and proteins, but the main source of plant-derived methanol is cell wall pectins, which are demethylesterified by pectin methylesterases (PMEs). Methanol emissions increase in response to mechanical wounding or other stresses due to damage of the cell wall, which is the main source of methanol production. Gaseous methanol from the wounded plant induces defense reactions in intact leaves of the same and neighboring plants, activating so-called methanol-inducible genes (MIGs) that regulate plant resistance to biotic and abiotic factors. Since PMEs are the key enzymes in methanol production, their expression increases in response to wounding, but after elimination of the stress factor effects, the plant cell should return to the original state. The amount of functional PMEs in the cell is strictly regulated at both the gene and protein levels. There is negative feedback between one of the MIGs, aldose epimerase-like protein, and PME gene transcription; moreover, the enzymatic activity of PMEs is modulated and controlled by PME inhibitors (PMEIs), which are also induced in response to pathogenic attack.

Keywords: cell wall, homogalacturonan, methanol, pectins, pectin methylesterase, pectin methylesterase inhibitor, plant immunity, stress

\section{INTRODUCTION}

Plants are the source of over a million metabolites (Cragg and Newman, 2013), including methanol, which was described back in 1661 by Robert Boyle as "sowrish spirit" in boxwood pyrolysis (Boyle, 1965). Originally, the out-dated name of methanol - wood alcohol - indicated its exceptional plant origin, but currently, it is known that endogenous metabolic methanol found in the human body can be not only a product of the plant diet but also a product of the life of microorganisms of the gastrointestinal tract and the processes of methylation-demethylation of DNA, RNA and proteins (Dorokhov et al., 2015). The source of endogenous plant methanol, as in the case of mammals, can be the process of demethylation of nucleic acids and proteins, but a cell wall pectin demethylesterification reaction is added to this process (Dorokhov et al., 2012).

In general, the source of metabolic methanol formation in plants is the demethylation of macromolecules (Figure 1). If the biochemical processes of methylation and demethylation of 
RNA, DNA and protein leading to methanol formation in animals and plants have a common mechanism (Dong et al., 2014), the demethylation of cell wall pectins with the participation of pectin methylesterases (PMEs) is purely a plant or microbial process (Dorokhov et al., 2015). In general, the polysaccharides of the primary cell wall of plants consist of cellulose, hemicellulose and pectins, which form a gellike matrix, determine cell adhesion, porosity and stiffness (Saffer, 2018). Polysaccharides of dicots and non-graminaceous monocots include polymers of galacturonic acid and are represented by three main types: homogalacturonan (HG) (65\% of total pectins), rhamnogalacturonan-I (RG-I) (20-35\%) and rhamnogalacturonan-II (RG-II) (10\% of pectins) (Atmodjo et al., 2013). HG is a homopolymer of (1-4)- $\alpha$-d-galacturonic acid (DGalA) in which up to $80 \%$ of carboxyl groups can be methylated (Figure 1).

Pectin methylesterases of higher plants encoded by a multigenic family (67 putative isoforms in Arabidopsis) (Wang et al., 2013) and are synthesized as precursor proteins that are cleaved at the stage of precursor delivery through the endoplasmic reticulum to the cell wall (Markovic et al., 2002; Louvet et al., 2006) with the removal of the leader sequence (Dorokhov et al., 2006). Although it is believed that the contribution of the processes of plant DNA and histone methylesterification/demethylesterification in the total release of methanol into the atmosphere by plants is negligible (Fall and Benson, 1996), these processes are important for understanding the epigenetic modifications of the plant genome (Gan et al., 2015; Zhang et al., 2018).

Methanol's role could be very significant, especially in transcriptional control, for example, via the regulation of the DNA methylation statuses of Arabidopsis thaliana RESISTANCE METHYLATED GENE 1 and WRKY22 in response to biotic stress (Deleris et al., 2016). In contrast to the participation of methanol in epigenetic processes, studies on the participation of pectins and PMEs in the formation of methanol in recent years have been devoted to the important role of methanol in plant development and in its response to stress effects (Dorokhov et al., 2012, 2015; Komarova et al., 2014a,b).

Here, we will consider the participation of methanol in plant life and its involvement in growth processes and the manifestation of protective responses against pathogens and adverse environmental factors.

\section{METHANOL PARTICIPATION IN PLANT GROWTH AND DEVELOPMENT}

The participation of methanol in growth and development is determined by the function of pectins in the formation of the cell wall. Pectin polysaccharides are synthesized in the cis-, medialand trans-Golgi (Sandhu et al., 2009; Atmodjo et al., 2013; Kim and Brandizzi, 2014, 2016). Numerous enzymes of pectin biosynthesis located in the Golgi apparatus were isolated and described, and their transmembrane type II topology assuming absence of a cleavable signal sequence was proved (Atmodjo et al., 2013). Methyl esterification of pectins probably occurs simultaneously with its synthesis (Atmodjo et al., 2013). With the help of secreted vesicles moving mainly along the actin cytoskeleton, pectins are delivered in a highly methylesterified form to the cell wall, which is building up at the stage of formation of the cell plate separating two new cells (Daher and Braybrook, 2015). The role of pectins in plant growth and development is evidenced by the phenotypes of Arabidopsis mutants and transgenic lines, in which the synthesis and modification of individual pectin polysaccharides is disrupted (Atmodjo et al., 2013; Saffer, 2018).

Plants with altered HG length also have multiple developmental defects, including an increased number of petals, variable phyllotaxis and early flowering, indicating that $\mathrm{HG}$ mechanical properties affect different developmental processes (Xiao et al., 2014, 2017). Mutants that affect pectin synthesis suffer from dwarfism and have decreased cell lengthening (Krupková et al., 2007; Saffer et al., 2017).

Methyl esterification of $\mathrm{HG}$ is a key determinant of cell wall properties, growth and leaf position (Peaucelle et al., 2008, 2012; Müller et al., 2013; Daher and Braybrook, 2015; LevesqueTremblay et al., 2015; Hocq et al., 2017). Since most HG is synthesized in the methyl esterified form, during the growth of the cells it can be demethylesterified by the action of the PME enzymes, which are in turn regulated by a pectin methylesterase inhibitors (PMEIs) (Wolf et al., 2009; Jolie et al., 2010). After demethylesterification, $\mathrm{HG}$ can form $\mathrm{Ca}^{2+}$-pectate-cross-linked complexes, referred to as "eggboxes," which strengthen the cell wall (Peaucelle et al., 2012; Daher and Braybrook, 2015). This process is observed, for example, during Nicotiana tabacum pollen tubes growth (Holdaway-Clarke et al., 2003; Bosch et al., 2005). On the other hand, increased PME activity correlates with the accumulation of demethylesterified HG in the Arabidopsis hypocotyl and apical meristem and leads to the cell wall loosening essential for growth symmetry breaking (Peaucelle et al., 2008, 2011, 2015; Figure 2A).

Pectin methylesterases interact with PMEIs to influence fruit development and ripening (Reca et al., 2012). Moreover, there are correlations between PME activity, the level of pectin deesterification and L-ascorbic acid production in the later stages of tomato fruit ripening (Rigano et al., 2018).

The participation of PMEs in the demethylesterification of HG inevitably leads to the formation of methanol. As a consequence, methanol emissions from plant leaves are much higher when the leaves are young and expanding than when they reach maturity (Nemecek-Marshall et al., 1995; Galbally and Kirstine, 2002; Oikawa et al., 2011). This phenomenon can also be observed in developing tobacco leaves at the stage of their transition from the state of acceptors (sink-leaves) of photoassimilates to the state of donors (source-leaves) (Burch-Smith and Zambryski, 2012). A similar sink-source modification occurs with the participation of tobacco PME producing methanol from pectins (Komarova et al., 2014a). When studying the role of methanol in the functioning of plasmodesmata in tobacco sink-leaves, an increased content of PME (EMBL Accession \#AJ401158) transcripts (Dorokhov et al., 2006) and raised concentration of methanol in the sap and tissues of immature leaves was found. Moreover, the genes for sieve element occlusion protein (SEOP), 


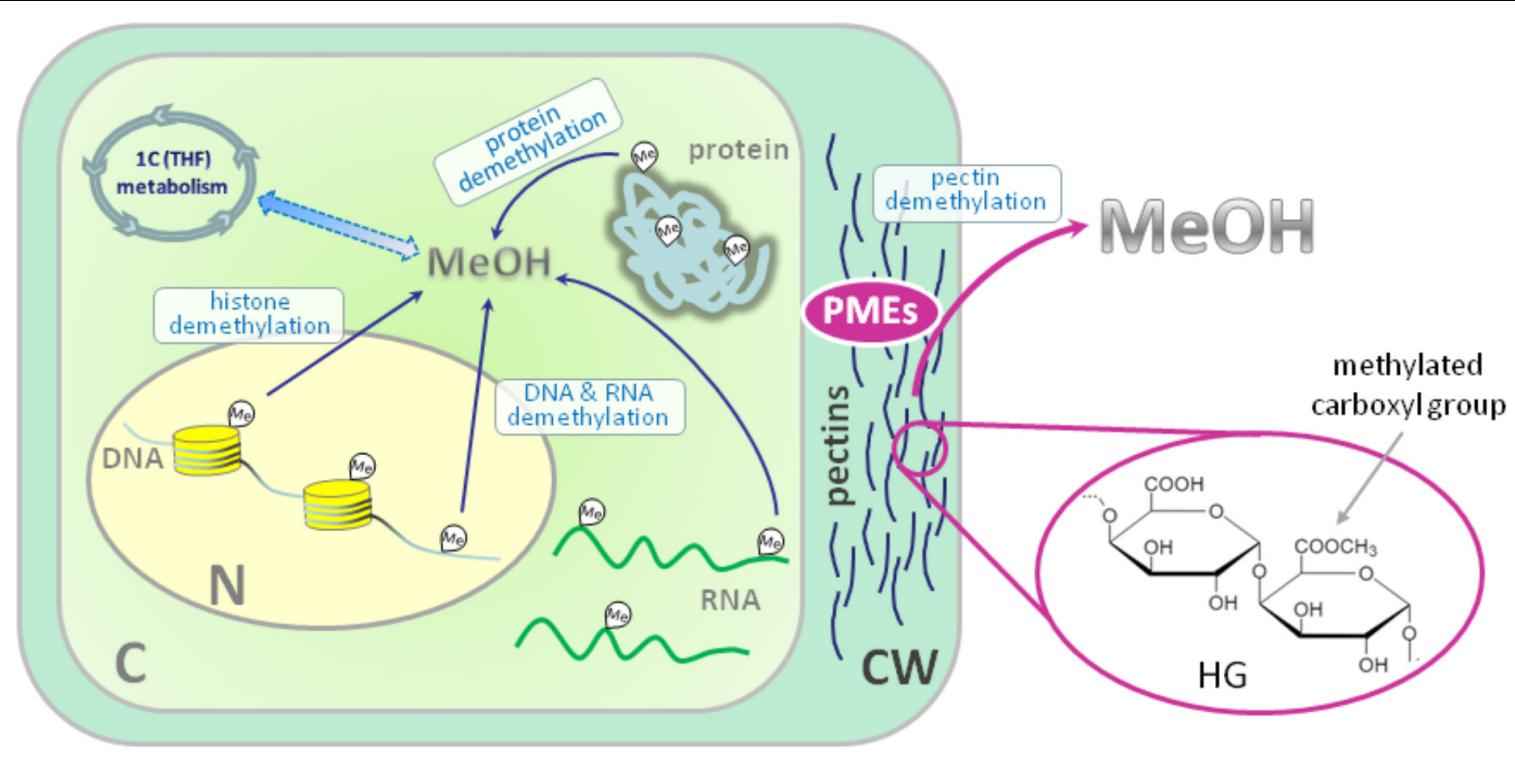

FIGURE 1 | Sources of endogenous methanol in plant cell. The main impact to overall cellular methanol production is made by pectin methylesterases (PMEs) in the reaction of cell wall pectin demethylesterification. PMEs digest ester bonds in the methylated homogalacturonan (HG) component of pectin releasing methanol. The other source of methanol in plant cell is the demethylation of such macromolecules as DNA, RNA and proteins. Methanol carbon could be included in cellular metabolic pathways: formaldehyde and formic acid formed from methanol make a contribution via the folate-driven one-carbon (1C) cycle in the biosynthesis of serine, methionine, as well as purines and thymidylate in nucleic acids. C, cytoplasm; N, nucleus; CW, cell wall; HG, homogalacturonan; MeOH, methanol; Me, methyl group; PMEs, pectin methylesterases; THF, tetrahydrofolate. Histones are designated with yellow cylinders.

auxin-repressed protein (ARP), salicylic acid binding catalase (SABC) involved in tobacco plant growth and signal transmission proved to be methanol-sensitive (Komarova et al., 2014a).

Methanol, formed during the demethylesterification of $\mathrm{HG}$, appears to also have a beneficial effect on the overall cellular metabolism. It is known that spraying plant leaves with $10-50 \%$ methanol can stimulate the photosynthetic activity and overall productivity of C3-plants (Nonomura and Benson, 1992). Although the mechanism responsible for this phenomenon is uncertain, it is assumed that formaldehyde and formic acid formed from methanol make a contribution via the folatedriven one-carbon (1C) cycle in the biosynthesis of serine, methionine, as well as purines and thymidylate in nucleic acids (Hanson and Roje, 2001). Moreover, $\left[{ }^{13} \mathrm{C}\right]$-labeled methanol was shown to enter cells of higher plants (Acer pseudoplatanus) in suspension culture and to be metabolized to $\left[3-{ }^{13} \mathrm{C}\right]$ serine, $\left[{ }^{13} \mathrm{CH}_{3}\right]$ methionine, and $\left[{ }^{13} \mathrm{CH}_{3}\right]$ phosphatidylcholine in addition to the induction of the methyl- $\beta$-d-glucopyranoside de novo synthesis (Gout et al., 2000).

\section{METHANOL EMISSION AS A STRESS SIGNAL AND ITS FEEDBACK CONTROL}

Because the cell wall separates and protects the cell from the environment (Malinovsky et al., 2014), the PMEs contained therein play a significant role in this defense mechanism (Komarova et al., 2014b). In addition to the direct effects of PMEs on tobacco cell wall, these enzymes also act via methanol released through the demethylesterification of pectins.
Mechanical damage (Dorokhov et al., 2012) and the attack of pathogens (von Dahl et al., 2006; Körner et al., 2009) increase the synthesis of tobacco PMEs, accelerate de-esterification processes and dramatically increase methanol emission (Lionetti et al., 2012; Komarova et al., 2014b; Dorokhov et al., 2015). Methanol is considered not only a by-product of PME activity but also a participant in cell signaling and an inducer of plant protection reactions (Tran et al., 2018). Transgenic tobacco plants with overexpression of the PME genes from A. thaliana or Aspergillus niger dramatically increased methanol emission and resistance to plant sap sucking pests Myzus persicae (aphid) and Bemisia tabaci (whitefly) (Dixit et al., 2013). Moreover, the released methanol can act as a signaling molecule that induces the defense responses of both the native plant and the leaves of the neighboring plant (Dorokhov et al., 2012). It has been suggested that methanol functions as a DAMP-like alarm signal, and it probably functions as an elicitor-active DAMP in monocot grasses (Hann et al., 2014). The signal function of methanol is to control the so-called MIGs that regulate plant resistance to abiotic and biotic factors (Dorokhov et al., 2012). Among the MIGs, are genes encoding aldose 1-epimerase-like protein (mutarotase) (AELP), PMEI and $\beta$-1,3-glucanase, involved in controlling the intercellular transport of macromolecules and creating favorable conditions for the reproduction of viruses but preventing bacterial colonization (Dorokhov et al., 2012, 2015; Komarova et al., 2014b). Moreover, methanol released into the air after a leaf injury results in a "priming" effect on intact leaves, setting the stage for the within-plant and neighboring plant immunity (Dorokhov et al., 2012). While the mechanism (direct or indirect) of the cellular impact of 
A

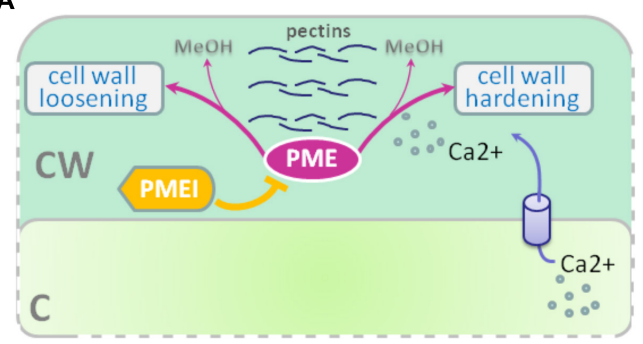

B

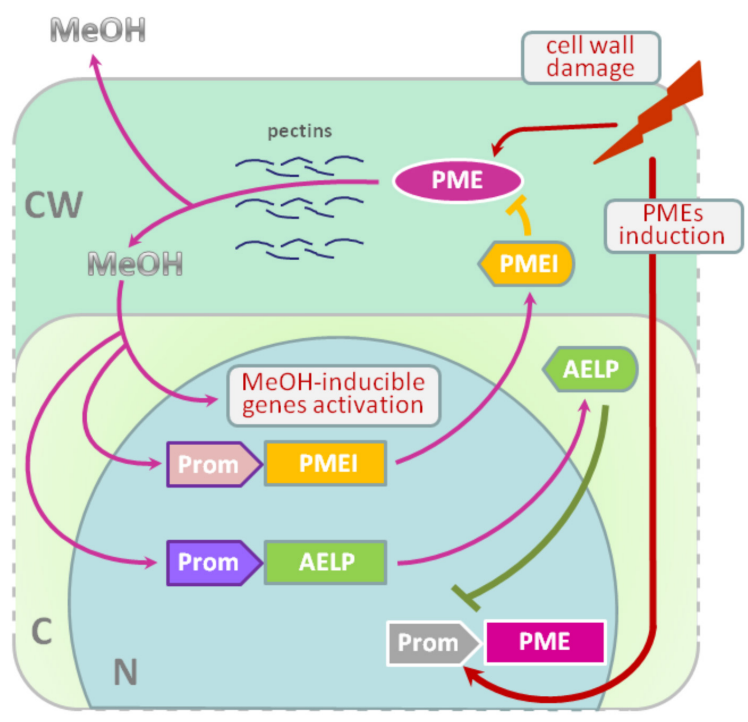

FIGURE 2 | PME-PMEl and PME-AELP feedback during growth and after stress impact. (A) Modification of cell wall as a result of the coordinated action of PMEs and PMEls. Demethylesterification is accompanied by cross-linking of $\mathrm{HG}$ molecules with $\mathrm{Ca}^{2+}$ ions, resulting in the strengthening of the cell wall, for example, during pollen tube growth. However, pectin demethylesterification can trigger the process leading to cell-wall loosening in apical meristem and hypocotyl, which is highly important for the shift from isotropic to anisotropic growth. (B) In fully expanded source leaves, PME activity is low but significantly increases under stress conditions, especially during the mechanical damage of tissues or pathogen attacks. As a result, de-esterification processes are accelerated and methanol emissions are dramatically increased. Methanol, in turn, activates methanol-inducible genes (MIGs), including aldose-epimerase-like protein (AELP), which is involved in intercellular transport and possibly controlling the transport and metabolism of sugars. Moreover, AELP negatively regulates PME gene transcription, making the cell return to a normal state after the end of the stress impact.

Methanol-mediated coordination of defense reactions is based on the feedback mechanism: when excess methanol is released, via its action on AELP and PMEls, it lowers the synthesis and activity of PME and returns the methanol emission rate to pre-stress state. C, cytoplasm; CW, cell wall; N, nucleus; PME, pectin methylesterase; PMEI, PME inhibitor; AELP, aldose epimerase-like protein; Prom, promoter region for AELP (purple), PMEI (pink) or PME (gray) genes; $\mathrm{MeOH}$, methanol.

an increase of physiological methanol is unclear, it can be assumed that one of methanol's functions is to control its own synthesis.

In general, prolonged and continuous exposure to stress factors, such as prolonged mechanical wind impact, accompanied by the synthesis of PMEs, causes irreversible changes in woody plants (Hamant and Moulia, 2016) like coniferous trees on Atlantic coastal cliffs (Jaffe and Forbes, 1993). Short-term effects do not lead to the significant changes and depletion of cellular biosynthetic resources (Bostock et al., 2014), since there is a mechanism for returning the cell to its original state when the PMEs synthesis and methanol emission are downregulated after the elimination of the stress factor impact. One of the key players of such control and regulation are PMEIs. For example, during $A$. thaliana infection by the necrotrophic pathogen Botrytis cinerea, PME activity and pectin demethylesterification are dynamically modulated by PMEIs (Lionetti et al., 2017).

Recently, another PME activity controlling mechanism was identified: the methanol-inducible gene AELP involved in intercellular transport and possibly controlling the transport and metabolism of sugars (Sheshukova et al., 2017) negatively regulates tobacco $P M E$ expression. The proposed model for the feedback regulation of gene expression involving PMEI and AELP suggests that when the cell wall is mechanically damaged, the $P M E$ genes are activated (Figure 2B); synthesis of PME and its secretion in the tobacco cell wall cause the active synthesis and emission of methanol, leading, in particular, to an increase in its concentration in the cytoplasm. This process is accompanied by induction of the PMEI genes and activation of the expression of the AELP gene through its methanol-inducible promoter. As shown in Figure 2B, AELP is capable of suppressing the transcription activity of the tobacco PME gene (Sheshukova et al., 2017) and reducing the level of methanol emission, which ultimately leads to a decrease in the transcription of the tobacco AELP gene. In accordance with this scheme, AELP proteins are likely to behave as transcription factors by inhibiting the expression of the PMEs in the nucleus and not in the apoplast.

Thus, the proposed model assumes the regulation of PMEs functioning at both the gene and protein levels.

\section{CONCLUSION}

Recent research has strengthened our view that endogenous metabolic methanol in plants not only is a by-product of biochemical processes of plant life but also performs an important signaling function. Influencing genes involved in the plasmodesmata gating and the intercellular transport of macromolecules, methanol participates in the controlled growth and development of plants (Dorokhov et al., 2012). Since the process of the maturation of cells after their division is accompanied by the essential PMEs-mediated demethylesterification of the cell wall $\mathrm{HG}$, this process inevitably leads to the formation of methanol, which affects the function of the genes involved in the development of the plant. Excess synthesis of methanol, for example, due to overexpression of $P M E$, which has been observed in transgenic tobacco plants (Hasunuma et al., 2004; Sheshukova et al., 2017), leads to dwarfism. Thus, methanol seems to be necessary for the coordinated work of the participants in the plant development program. The same methanol-mediated coordination is observed 
during the development of plant protective reactions in response to abiotic and biotic stresses. Methanol as a gaseous substance is released into the air after a violation of the integrity of the cell wall and has a "priming" effect on intact leaves, as if preparing them for a possible attack by the aggressor (Dorokhov et al., 2012). At the heart of methanol-mediated coordination of defense reactions lies the feedback mechanism: when excess methanol is released, it acts on tobacco AELP (Sheshukova et al., 2017) and PMEI (Lionetti et al., 2017), lowering the synthesis and activity of PME and returning the methanol emission rate to a pre-stress state.

\section{REFERENCES}

Atmodjo, M. A., Hao, Z., and Mohnen, D. (2013). Evolving views of pectin biosynthesis. Annu. Rev. Plant Biol. 64, 747-779. doi: 10.1146/annurev-arplant042811-105534

Bosch, M., Cheung, A. Y., and Hepler, P. K. (2005). Pectin methylesterase, a regulator of pollen tube growth. Plant Physiol. 138, 1334-1346. doi: 10.1104/ pp.105.059865

Bostock, R. M., Pye, M. F., and Roubtsova, T. V. (2014). Predisposition in plant disease: exploiting the nexus in abiotic and biotic stress perception and response. Annu. Rev. Phytopathol. 52, 517-549. doi: 10.1146/annurev-phyto081211-172902

Boyle, R. (1965). “The sceptical chymist; or, Chymico-physical doubts \& paradoxes, touching the spagyrist's principles commonly call'd hypostatical, as they are wont to be propos'd and defended by the generality of alchymists," in Whereunto is Praemis'd Part of Another Discourse Relating to the Same Subject, eds F. Cadwell and F. Crooke (London: Dawsons of Pall Mall).

Burch-Smith, T. M., and Zambryski, P. C. (2012). Plasmodesmata paradigm shift: regulation from without versus within. Annu. Rev. Plant Biol. 63, 239-260. doi: 10.1146/annurev-arplant-042811-105453

Cragg, G. M., and Newman, D. J. (2013). Natural products: a continuing source of novel drug leads. Biochim. Biophys. Acta 1830, 3670-3695. doi: 10.1016/j. bbagen.2013.02.008

Daher, F. B., and Braybrook, S. A. (2015). How to let go: pectin and plant cell adhesion. Front. Plant Sci. 6:523. doi: 10.3389/fpls.2015.00523

Deleris, A., Halter, T., and Navarro, L. (2016). DNA methylation and demethylation in plant immunity. Annu. Rev. Phytopathol. 54, 579-603. doi: 10.1146/annurevphyto-080615-100308

Dixit, S., Upadhyay, S. K., Singh, H., Sidhu, O. P., Verma, P. C., and Chandrashekar, K. (2013). Enhanced methanol production in plants provides broad spectrum insect resistance. PLoS One 8:e79664. doi: 10.1371/journal. pone.0079664

Dong, C., Zhang, H., Xu, C., Arrowsmith, C. H., and Min, J. (2014). Structure and function of dioxygenases in histone demethylation and DNA/RNA demethylation. IUCrJ 1, 540-549. doi: 10.1107/S2052252514020922

Dorokhov, Y. L., Komarova, T. V., Petrunia, I. V., Frolova, O. Y., Pozdyshev, D. V., and Gleba, Y. Y. (2012). Airborne signals from a wounded leaf facilitate viral spreading and induce antibacterial resistance in neighboring plants. PLoS Pathog. 8:e1002640. doi: 10.1371/journal.ppat.1002640

Dorokhov, Y. L., Shindyapina, A. V., Sheshukova, E. V., and Komarova, T. V. (2015). Metabolic methanol: molecular pathways and physiological roles. Physiol. Rev. 95, 603-644. doi: 10.1152/physrev.00034.2014

Dorokhov, Y. L., Skurat, E. V., Frolova, O. Y., Gasanova, T. V., Ivanov, P. A., Ravin, N. V., et al. (2006). Role of the leader sequence in tobacco pectin methylesterase secretion. FEBS Lett. 580, 3329-3334. doi: 10.1016/j.febslet.2006.04.090

Fall, R., and Benson, A. A. (1996). Leaf methanol - the simplest natural product from plants. Trends Plant Sci. 1, 296-301. doi: 10.1016/S1360-1385(96)88175-0

Galbally, I. E., and Kirstine, W. (2002). The production of methanol by flowering plants and the global cycle of methanol. J. Atmospheric Chem. 43, 195-229. doi: 10.1023/A:1020684815474

Gan, E.-S., Xu, Y., and Ito, T. (2015). Dynamics of H3K27me3 methylation and demethylation in plant development. Plant Signal. Behav. 10:e1027851. doi: 10.1080/15592324.2015.1027851

\section{AUTHOR CONTRIBUTIONS}

YD, ES, and TK conceived the concept, prepared, revised, and finalized the manuscript. All the authors read and approved the manuscript.

\section{FUNDING}

This work was supported by the Russian Foundation for Basic Research (Project No. 17-29-08012).

Gout, E., Aubert, S., Bligny, R., Rébeillé, F., Nonomura, A. R., Benson, A. A., et al. (2000). Metabolism of methanol in plant cells. Carbon-13 nuclear magnetic resonance studies. Plant Physiol. 123, 287-296. doi: 10.1104/pp.123.1.287

Hamant, O., and Moulia, B. (2016). How do plants read their own shapes? New Phytol. 212, 333-337. doi: 10.1111/nph.14143

Hann, C. T., Bequette, C. J., Dombrowski, J. E., and Stratmann, J. W. (2014). Methanol and ethanol modulate responses to danger- and microbeassociated molecular patterns. Front. Plant Sci. 5:550. doi: 10.3389/fpls.2014. 00550

Hanson, A. D., and Roje, S. (2001). One-carbon metabolism in higher plants. Annu. Rev. Plant Physiol. Plant Mol. Biol. 52, 119-137. doi: 10.1146/annurev.arplant. 52.1.119

Hasunuma, T., Fukusaki, E., and Kobayashi, A. (2004). Expression of fungal pectin methylesterase in transgenic tobacco leads to alteration in cell wall metabolism and a dwarf phenotype. J. Biotechnol. 111, 241-251. doi: 10.1016/j.jbiotec.2004. 04.015

Hocq, L., Pelloux, J., and Lefebvre, V. (2017). Connecting homogalacturonan-type pectin remodeling to acid growth. Trends Plant Sci. 22, 20-29. doi: 10.1016/j. tplants.2016.10.009

Holdaway-Clarke, T. L., Weddle, N. M., Kim, S., Robi, A., Parris, C., Kunkel, J. G., et al. (2003). Effect of extracellular calcium, $\mathrm{pH}$ and borate on growth oscillations in Lilium formosanum pollen tubes. J. Exp. Bot. 54, 65-72. doi: 10.1093/jxb/erg004

Jaffe, M. J., and Forbes, S. (1993). Thigmomorphogenesis: the effect of mechanical perturbation on plants. Plant Growth Regul. 12, 313-324. doi: 10.1007/ BF00027213

Jolie, R. P., Duvetter, T., Van Loey, A. M., and Hendrickx, M. E. (2010). Pectin methylesterase and its proteinaceous inhibitor: a review. Carbohydr. Res. 345, 2583-2595. doi: 10.1016/j.carres.2010.10.002

Kim, S.-J., and Brandizzi, F. (2014). The plant secretory pathway: an essential factory for building the plant cell wall. Plant Cell Physiol. 55, 687-693. doi: $10.1093 / \mathrm{pcp} / \mathrm{pct} 197$

Kim, S.-J., and Brandizzi, F. (2016). The plant secretory pathway for the trafficking of cell wall polysaccharides and glycoproteins. Glycobiology 26, 940-949. doi: 10.1093/glycob/cww044

Komarova, T. V., Pozdyshev, D. V., Petrunia, I. V., Sheshukova, E. V., and Dorokhov, Y. L. (2014a). Pectin methylesterase-generated methanol may be involved in tobacco leaf growth. Biochem. Mosc. 79, 102-110. doi: 10.1134/ S0006297914020035

Komarova, T. V., Sheshukova, E. V., and Dorokhov, Y. L. (2014b). Cell wall methanol as a signal in plant immunity. Front. Plant Sci. 5:101. doi: 10.3389/ fpls.2014.00101

Körner, E., von Dahl, C. C., Bonaventure, G., and Baldwin, I. T. (2009). Pectin methylesterase NaPME1 contributes to the emission of methanol during insect herbivory and to the elicitation of defence responses in Nicotiana attenuata. J. Exp. Bot. 60, 2631-2640. doi: 10.1093/jxb/erp106

Krupková, E., Immerzeel, P., Pauly, M., and Schmülling, T. (2007). The tumorous shoot development 2 gene of Arabidopsis encoding a putative methyltransferase is required for cell adhesion and co-ordinated plant development. Plant J. Cell Mol. Biol. 50, 735-750. doi: 10.1111/j.1365-313X.2007.03123.x

Levesque-Tremblay, G., Pelloux, J., Braybrook, S. A., and Müller, K. (2015). Tuning of pectin methylesterification: consequences for cell wall biomechanics and development. Planta 242, 791-811. doi: 10.1007/s00425-015-2358-5 
Lionetti, V., Cervone, F., and Bellincampi, D. (2012). Methyl esterification of pectin plays a role during plant-pathogen interactions and affects plant resistance to diseases. J. Plant Physiol. 169, 1623-1630. doi: 10.1016/j.jplph.2012.05.006

Lionetti, V., Fabri, E., De Caroli, M., Hansen, A. R., Willats, W. G. T., Piro, G., et al. (2017). Three pectin methylesterase inhibitors protect cell wall integrity for Arabidopsis immunity to Botrytis. Plant Physiol. 173, 1844-1863. doi: 10.1104/pp.16.01185

Louvet, R., Cavel, E., Gutierrez, L., Guénin, S., Roger, D., Gillet, F., et al. (2006). Comprehensive expression profiling of the pectin methylesterase gene family during silique development in Arabidopsis thaliana. Planta 224, 782-791. doi: 10.1007/s00425-006-0261-9

Malinovsky, F. G., Fangel, J. U., and Willats, W. G. T. (2014). The role of the cell wall in plant immunity. Front. Plant Sci. 5:178. doi: 10.3389/fpls.2014.00178

Markovic, O., Cederlund, E., Griffiths, W. J., Lipka, T., and Jörnvall, H. (2002). Characterization of carrot pectin methylesterase. Cell. Mol. Life Sci. 59, 513-518. doi: 10.1007/s00018-002-8442-6

Müller, K., Levesque-Tremblay, G., Bartels, S., Weitbrecht, K., Wormit, A., Usadel, B., et al. (2013). Demethylesterification of cell wall pectins in Arabidopsis plays a role in seed germination. Plant Physiol. 161, 305-316. doi: 10.1104/pp.112.205724

Nemecek-Marshall, M., MacDonald, R. C., Franzen, J. J., Wojciechowski, C. L., and Fall, R. (1995). Methanol emission from leaves (enzymatic detection of gasphase methanol and relation of methanol fluxes to stomatal conductance and leaf development). Plant Physiol. 108, 1359-1368. doi: 10.1104/pp.108.4.1359

Nonomura, A. M., and Benson, A. A. (1992). The path of carbon in photosynthesis: improved crop yields with methanol. Proc. Natl. Acad. Sci. U.S.A. 89, 9794-9798. doi: 10.1073/pnas.89.20.9794

Oikawa, P. Y., Giebel, B. M., Sternberg, L. d. S. L. O., Li, L., Timko, M. P., Swart, P. K., et al. (2011). Leaf and root pectin methylesterase activity and ${ }^{13} \mathrm{C} /{ }^{12} \mathrm{C}$ stable isotopic ratio measurements of methanol emissions give insight into methanol production in Lycopersicon esculentum. New Phytol. 191, 10311040. doi: 10.1111/j.1469-8137.2011.03770.x

Peaucelle, A., Braybrook, S., and Höfte, H. (2012). Cell wall mechanics and growth control in plants: the role of pectins revisited. Front. Plant Sci. 3:121. doi: $10.3389 /$ fpls.2012.00121

Peaucelle, A., Braybrook, S. A., Le Guillou, L., Bron, E., Kuhlemeier, C., and Höfte, H. (2011). Pectin-induced changes in cell wall mechanics underlie organ initiation in Arabidopsis. Curr. Biol. 21, 1720-1726. doi: 10.1016/j.cub.2011. 08.057

Peaucelle, A., Louvet, R., Johansen, J. N., Höfte, H., Laufs, P., Pelloux, J., et al. (2008). Arabidopsis phyllotaxis is controlled by the methyl-esterification status of cell-wall pectins. Curr. Biol. 18, 1943-1948. doi: 10.1016/j.cub.2008.10.065

Peaucelle, A., Wightman, R., and Höfte, H. (2015). The control of growth symmetry breaking in the Arabidopsis hypocotyl. Curr. Biol. 25, 1746-1752. doi: 10.1016/ j.cub.2015.05.022

Reca, I. B., Lionetti, V., Camardella, L., D’Avino, R., Giardina, T., Cervone, F., et al. (2012). A functional pectin methylesterase inhibitor protein (SolyPMEI) is expressed during tomato fruit ripening and interacts with PME-1. Plant Mol. Biol. 79, 429-442. doi: 10.1007/s11103-012-9921-2

Rigano, M. M., Lionetti, V., Raiola, A., Bellincampi, D., and Barone, A. (2018). Pectic enzymes as potential enhancers of ascorbic acid production through the
D-galacturonate pathway in Solanaceae. Plant Sci. Int. J. Exp. Plant Biol. 266, 55-63. doi: 10.1016/j.plantsci.2017.10.013

Saffer, A. M. (2018). Expanding roles for pectins in plant development. J. Integr. Plant Biol. 60, 910-923. doi: 10.1111/jipb.12662

Saffer, A. M., Carpita, N. C., and Irish, V. F. (2017). Rhamnose-containing cell wall polymers suppress helical plant growth independently of microtubule orientation. Curr. Biol. 27, 2248.e-2259.e. doi: 10.1016/j.cub.2017.06.032

Sandhu, A. P. S., Randhawa, G. S., and Dhugga, K. S. (2009). Plant cell wall matrix polysaccharide biosynthesis. Mol. Plant 2, 840-850. doi: 10.1093/mp/ssp056

Sheshukova, E. V., Komarova, T. V., Pozdyshev, D. V., Ershova, N. M., Shindyapina, A. V., Tashlitsky, V. N., et al. (2017). The intergenic interplay between aldose 1-epimerase-like protein and pectin methylesterase in abiotic and biotic stress control. Front. Plant Sci. 8:1646. doi: 10.3389/fpls.2017.01646

Tran, D., Dauphin, A., Meimoun, P., Kadono, T., Nguyen, H. T. H., ArbeletBonnin, D., et al. (2018). Methanol induces cytosolic calcium variations, membrane depolarization and ethylene production in Arabidopsis and tobacco. Ann. Bot. doi: 10.1093/aob/mcy038 [Epub ahead of print].

von Dahl, C. C., Hävecker, M., Schlögl, R., and Baldwin, I. T. (2006). Caterpillar-elicited methanol emission: a new signal in plant-herbivore interactions? Plant J. Cell Mol. Biol. 46, 948-960. doi: 10.1111/j.1365-313X.2006. 02760.x

Wang, M., Yuan, D., Gao, W., Li, Y., Tan, J., and Zhang, X. (2013). A comparative genome analysis of PME and PMEI families reveals the evolution of pectin metabolism in plant cell walls. PLoS One 8:e72082. doi: 10.1371/journal.pone. 0072082

Wolf, S., Mouille, G., and Pelloux, J. (2009). Homogalacturonan methylesterification and plant development. Mol. Plant 2, 851-860. doi: 10.1093/mp/ ssp066

Xiao, C., Barnes, W. J., Zamil, M. S., Yi, H., Puri, V. M., and Anderson, C. T. (2017). Activation tagging of Arabidopsis POLYGALACTURONASE INVOLVED IN EXPANSION2 promotes hypocotyl elongation, leaf expansion, stem lignification, mechanical stiffening, and lodging. Plant J. 89, 1159-1173. doi: $10.1111 /$ tpj. 13453

Xiao, C., Somerville, C., and Anderson, C. T. (2014). Polygalacturonase involved in expansion 1 functions in cell elongation and flower development in Arabidopsis. Plant Cell 26, 1018-1035. doi: 10.1105/tpc.114.123968

Zhang, H., Lang, Z., and Zhu, J.-K. (2018). Dynamics and function of DNA methylation in plants. Nat. Rev. Mol. Cell Biol. 19, 489-506. doi: 10.1038/ s41580-018-0016-z

Conflict of Interest Statement: The authors declare that the research was conducted in the absence of any commercial or financial relationships that could be construed as a potential conflict of interest.

Copyright (c) 2018 Dorokhov, Sheshukova and Komarova. This is an open-access article distributed under the terms of the Creative Commons Attribution License (CC BY). The use, distribution or reproduction in other forums is permitted, provided the original author(s) and the copyright owner(s) are credited and that the original publication in this journal is cited, in accordance with accepted academic practice. No use, distribution or reproduction is permitted which does not comply with these terms. 